\title{
EFEKTIVITAS KONSELING KELOMPOK RATIONAL EMOTIVE BEHAVIOUR THERAPY UNTUK MEMINIMALISIR TINGKAT PERGAULAN BEBAS SISWA KELAS XI AKUTANSI SMK 17 AGUSTUS 1945 MUNCAR
}

\author{
Meiliana Eka Fratiwi ${ }^{1}$, Raup Padillah ${ }^{2}$ \\ Fakultas Keguruan dan Ilmu Pendidikan, Universitas PGRI Banyuwangi \\ Email : memecantek01@gmail.com ${ }^{1}$ \\ Email : raup.padillah@gmail.com ${ }^{2}$
}

\begin{abstract}
Abstrak
Adanya permasalahan yang terjadi yakni pergaulan bebas pada siswa. peneliti memberikan solusi dalam menanggulangi dan meminimalisir tingginya pergaulan bebas. Menggunakan metode konseling kelompok REBT, metode ini sangat efektif dalam penanggulangan problem yang ada. Kelebihan dari metode konseling kelompok REBT ini yaitu, pendekatan REBT jelas dan mudah di mengerti, pendekatan REBT dapat dengan mudahnya dikombinasikan dengan teknik tingkah laku, pendekatan REBT lebih relative singkat, pendekatan ini telah banyak menjadi literatur dan penelitian. Metode penelitian yang digunakan adalah metode penelitian kuantitatif dengan langkah-langkah meliputi populasi penelitian, sampling, rancangan penelitian, prosedur penelitian, variabel penelitian dan devinisi variabel, metode pengumpulan data dan instrument, metode analisis data.
\end{abstract}

Kata Kunci: REBT, Pergaulan Bebas, Siswa

\begin{abstract}
The existence of problems that occur ie free association in students. researchers provide solutions in tackling and minimizing high promiscuity. Using the REBT group counseling method, this method is very effective in addressing existing problems. The advantages of this REBT group counseling method is that REBT approach is clear and easy to understand, REBT approach can be easily combined with behavioral techniques, REBT approach is relatively short, this approach has become a lot of literature and research. The research method used is quantitative research method with the steps include population research, sampling, research design, research procedures, research variables and devinisi variables, data collection methods and instruments, methods of data analysis.
\end{abstract}

Keywords: $R E B T$, promiscuity, students 


\section{PENDAHULUAN}

Pendidikan pada dasarnya adalah kebutuhan jasmani maupun rohani manusia. Hal ini sudah dimulai sejak awal kehidupan manusia, oleh sebab itu perlunya pendidikan kepada setiap manusia sebagai alat untuk memanusiakan manusia. Salah satu yang akan membantu proses tersebut dalam pendidikan di sekolah ialah bimbingan dan konseling. Bimbingan dan konseling adalah bantuan yang bertujuan untuk membantu peserta didik dalam pembentukan karakter dan pribadi yang lebih baik. Sehingga dalam hal ini bimbingan dan konseling melakukan pemecahan masalah atau pengarahan dalam hal menanggulangi pergaulan bebas pada remaja.

Masa remaja merupakan masa peralihan dari masa kanak-kanak menuju masa dewasa. Masa dimana terjadinya tahap perkembangan manusia yang tentunya berbeda dengan masa sebelumnya maupun sesudahnya serta memiliki ciri khas. Seorang remaja banyak menghadapi permasalahan pergaulan bebas. Masa remaja ialah suatu waktu kritis untuk pengembangan akhlak, nilainilai, dan kebiasaan yang hanya akan dirasakan satu kali seumur hidupnya untuk dituntut menjadi kader yang dihadapkan pada tantangan global. Namun, yang terjadi pada remaja saat ini ialah maraknya kasus-kasus perilaku seks bebas yang mengakibatkan kehamilan di luar nikah, pemerkosaan merebaknya pelacuran di kalangan remaja, aborsi, penyakit menular seksual, pelecehan seksual dan penyimpangan-penyimpangan seksual.
Indonesia secara garis besar mayoritas penduduk beragama Islam, permasalahan pergaulan bebas sudah menjadi masalah sosial yang sampai saat ini, belum dapat diatasi secara tuntas. Akibat yang ditimbulkan cukup serius dan tidak dapat dianggap lagi sebagai suatu persoalan sederhana, karena tindakan tersebut merupakan tindakan yang melanggar norma dan merugikan generasi muda bangsa. Kondisi ini sangat memprihatinkan masyarakat khususnya para orang tua dan para guru, hal ini disebabkan karena pelaku dan korbannya sebagian besar adalah kaum muda (remaja). Menurut Gunarsa (2012:50), pergaulan bebas berarti pergaulan yang luas antara pemuda dan pemudi. Tidak terlalu menekankan pengelompokan yang kompak antara dua orang saja, akan tetapi antara banyak muda-mudi.Rangka untuk mencegah pengaruh pergaulan bebas di kalangan siswa remaja, peran guru pembimbing sangatlah penting di dalam memberikan bimbingan serta menumbuhkan penalaran siswa. Bimbingan dan konseling merupakan integral dari program pendidikan di sekolah yang sasarannya adalah memberikan bantuan psikologis dan kemanusiaan secara ilmiah.

Natawidjaya (dalam Wibowo, 2009:32) yang mengemukakan bahwa konseling kelompok merupakan upaya bantuan kepada individu dalam suasana kelompok yang bersifat pencegahan dan penyembuhan, dan diarahkan kepada pemberian kemudahan dalam rangka perkembangan dan pertumbuhannya. Fenomena melakukan hubungan seksual pranikah di kalangan remaja, sudah 
banyak ditemukan dikalangan generasi muda. Hal ini mengakibatkan dampak buruk seperti: penyakit menular seksual, terjakit penyakit HIV/AIDS, hamil diluar nikah bagi wanita, aborsi, trauma kejiwaan, hancurnya masa depan, aib bagi keluarga dan diri sendiri.

Menurut Rahardjo (2008:75) bentuk-bentuk perilaku sosial bebas yang biasa dilakukan ialah (1) Kissing atau perilaku berciuman, mulai dari ciuman ringan sampai deep kissing, (2) necking atau perilaku mencium daerah sekitar leher pasangan, (3) petting atau segala bentuk kontak fisik seksual berat tapi tidak termasuk intercourse, baik ini light petting (meraba payudara dan alat kelamin pasangan) atau hard petting (menggosokkan alat kelamin sendiri ke alat kelamin pasangan, baik dengan berbusana atau tanpa busana), dan (4) intercourse atau penetrasi alat kelamin pria ke alat kelamin wanita. Sehingga pada dasarnya hal ini sering terjadi pada remaja masa kini di seluruh Indonesia, yang notabenenya adalah pelajar sekolah.

Kota Banyuwangi pada saat ini merupakan kota yang menjadi sorotan di wilayah jawa timur yang di mana dari sektor pembangunan sangat berkembang pesat. Berdasarkan data yang dihimpun Kelompok Kerja Bina Sehat (KKBS) Di Banyuwangi, Jawa Timur, rata-rata ada 2.345 lelaki di wilayah itu yang dengan sengaja membeli seks. Di balik itu semua ternyata juga ada dampak negatif, dimana dalam hal ini Kota Banyuwangi memiliki angka penyebaran Virus HIV/AIDS nomor tiga wilayah Jawa Timur setelah Kota Surabaya dan Malang. Hal ini di utarakan oleh Tunggul Harwanto, Manajer Program
KKBS bahwa telah di temukan kasus HIV sejumlah 1.912 Tahun 2015 di Kabupaten Banyuwangi. Mayoritas terbanyak yang menjangkit virus HIV adalah golongan remaja, bahwa sanya hal ini di sebabkan dari pergaulan bebas (sex bebas) . Dari data menurut Choirun (2016) ada 4 pengidap HIV/AIDS tertinggi di Banyuwangi, (1) Banyuwangi kota dengan jumlah 496 penderita, (2) Kecamatan Genteng 164 penderita, (3) Muncar dengan 133 penderita, (4) Srono 118 penderita. Dari data teresebut didapatkan wilayah Kecamatan Muncar menjadi nomer 3 tingkat tingginya yang terjangkit Virus HIV, yakni mereka adalah golongan remaja. Dengan data tingginya pengidap HIV/AIDS bahwasanya hal tersebut menjadi dampak dari pergaulan bebas (sex bebas).

Adanya ujaran dari masyarakat sekitar (Iswandi, 55Thn) mengungkapkan bahwasannya, siswa - siswi SMK 17 Agustus 1945 Muncar yang bersekolah di sana terkenal dengan perilaku pergaulan bebas. Hal ini di tunjukan dengan perilaku - perilaku siswa - siswi saat bersekolah dan di luar sekolah. Contoh - contoh perilaku siswa - siswi ang bersekolah di sana antara lain : merokok, berpacaran terlewat batas ( berciuman, perilaku sexsual,), Minum - minuman keras, dan perilaku lainnya. Adanya pandangan seperti itu di masyarakat, sehingga para orang tua yang mempunyai anak yang akan menginjak sekolah menengah atas tidak setuju untuk mensekolahkan anak anaknya di SMK 17 Agustus 1945 Muncar. Karena orang tua takut jika anaknya terjerumus dalam pergaulan bebas. 
Adanya permasalahan yang terjadi yakni pergaulan bebas pada siswa. peneliti memberikan solusi dalam menanggulangi dan meminimalisis tingginya pergaulan bebas. Menggunakan metode konseling kelompok REBT, hal ini metode ini sangat efektif dalam menanggulangan problem yang ada. Kelebihan dari metode konseling kelompok REBT ini yaitu, pendekatan REBT jelas dan mudah di mengerti, pendekatan REBT dapat dengan mudahnya dapat dikombinasikan dengan teknik tingkah laku, pendekatan REBT lebih relative singkat, pendektan ini telah banyak menjadi literatur dan penelitian.

Penelitian yangdi lakukan ini akan menggunakan Pendekatan RationalEmotive BehaviorTherapy (REBT). REBT adalah pendekatan behavior kognitif yang menekankan pada keterkaitan antara perasaan, tingkah laku dan pikiran. Pendekatan Rational-Emotive Behavior Therapy (REBT) di kembangkan oleh Albert Ellis melalui beberapa tahapan. pandangan dasar pendekatan ini tentang manusia adalah bahwa individu memiliki tendensi untuk berpikir irasional yang salah satunya didapat melalui belajar sosial. Di samping itu, individu juga memiliki kapasitas untuk belajar kembali untuk berpikir rasional. pendekatan ini bertujuan untuk mengajak individu mengubah pikiran-pikiran irasionalnya ke pikiran yang rasional melalui teori ABCDE. Pendekatan konseling Rational Emotive Behavioural Therapy merupakan pendekatan yang bertujuan untuk mengubah keyakinan irrasional yang dimiliki klien (yang memberikan dampak pada emosi dan perilaku) menjadi rasional.
Pendekatan REBT membagi empat keyakinan yang irrasional dan 4 keyakinan rasional sebagai alternatife. Tuntutan merupakan keyakinan irrasional yang pertama dan utama. Terdapat 3 macam tuntutan, terhadap diri sendiri, orang lain, dan kehidupan. Tuntutan merupakan akar dari munculnya keyakinan irrasional yang lain meliputi yakin akan sangat menderita, yakin tidak dapat mentolerir frustasi, dan yakin pasti mengalami depresi. Keyakinan irrasional sebenarnya dapat diganti dengan keyakinan rasional ketika individu memiliki keinginan yang tidak dogmatis (lawan dari tuntutan). Keyakinan individu untuk memiliki keinginan yang tidak dogmatis merupakan akar dari munculnya keyakinan rasional yang lain, meliputi; yakin tidak akan sangat menderita, yakin dapat mentolerir frustasi, dan yakin dapat menerima kenyataan. Rational Emotive Behavior Therapy (REBT) yang akan dituangkan dalam tulisan ini yaitu konsep konselor membantu untuk meminimalisir tingkat tingginya pergaulan bebas para remaja sekolah di Kecamatan Muncar.

Tingginya pergaulan bebas di Kota Banyuwangi Khususnya wilayah Kecamatan Muncar, sehingga penulis melakukan penelitian yang bertujuan untuk mengurangi tingkat pergaulan bebas remaja khususnya para siswa.Dengan melakukan konseling kelompok Rational Emotive Behavior Therapy.

Maka dapat diidentifikasi masalahmasalah sebagai berikut :1) Kurangnya wawasan pergaulan bebas (seks bebas), yang membuat rasa penasaran dan ingin tahu. 2) Pengaruh negatif dari lingkungan yang menyebabkan anak tersebut terjun dalam pergaulan bebas. 3) Perkembangan 
teknologi yang semakin canggih dimana di media elektronik, seperti internet terdapat iklan atau situs - situs porno yang sangat mudah untuk di akses.

Tujuan Penelitian : 1) Untuk menguji konseling Rational Emotive Behavior Therapyefektif untukmeminimalisir tingkat pergaulan bebas pada siswa kelasXI Akutansi SMK 17 Agustus 1945 Muncar. 2) Untuk mengujiperbedaan penurunan tingkat pergaulan bebas antara kelompok eksperimen dan kelompok control

\section{METODE PENELITIAN}

\section{Populasi Penelitian}

Wilayah generalisasi yang terdiri atas: obyek atau subyek yang mempunyai kualitas dan karakteristik tertentu yang ditetapkan oleh peneliti untuk dipelajari dan kemudian ditarik kesimpulannya (Sugiyono, 2011:80)

Populasi yang digunakan pada penelitian ini adalah siswa kelas XI Akutansi di SMK 17 Agustus 1945 Muncar dengan jumlah populasi sebanyak 90 siswa.

\section{Tabel 01. Populasi Penelitian}

\begin{tabular}{|l|c|c|}
\hline No & Kelas & Jumlah siswa \\
\hline 1 & XI Akutansi 1 & 30 \\
\hline 2 & XI Akutansi 2 & 29 \\
\hline 3 & XI Akutansi 3 & 31 \\
\hline \multicolumn{2}{|c|}{ Jumlah } & 90 siswa \\
\hline
\end{tabular}

\section{Sampling}

\section{a. Pengertian Sampling}

Menurut Sugiyono (2016:81)

Sampling adalah bagian dari jumlah dan karakteristik yang dimiliki oleh populasi. Bila populasi besar, dan penelitian tidak mungkin mempelajari semua yang ada pada populasi, misalnya karena keterbatasan dana, tenaga dan waktu, maka peneliti dapat menggunakan sampel yang diambil dari populasi itu. Apa yang dipelajari dari sampel, kesimpulannya akan dapat diberlakukan untuk populasi. Untuk ini sampel yang diambil dari populasi harus betul-betul representative (mewakili).

Menurut Sugiyono (2016:85) Purposive Sampling adalah Teknik penentuan sampling dengan pertimbangan tertentu. Pada penelitian ini akan menggunakan purposive sampling. Pada penelitian ini menggunakan 40 butir.

Kriteria purposive sampling:

$\mathrm{Mi}=\frac{1}{2}$ (skor tertinggi ideal + skor terendah ideal)

$\mathrm{SDi}=\frac{1}{6}$ (skor tertinggi ideal - skor terendah ideal)

\section{Tabel 02. Kategori Penskoran}

\begin{tabular}{|c|c|}
\hline Kategori Penskoran & Kategori \\
\hline $\mathrm{Mi}+1,5 \mathrm{SDi}<$ & Sangat Tinggi \\
\hline $\mathrm{Mi}+0,5 \mathrm{SDi}<\mathrm{X}<\mathrm{Mi}$ & Tinggi \\
$+1,5 \mathrm{Sdi}$ & \\
\hline $\mathrm{Mi}-0,5 \mathrm{SDi}<\mathrm{X}<\mathrm{Mi}$ & Cukup \\
$+0,5 \mathrm{Sdi}$ & \\
\hline $\mathrm{Mi}-1,5 \mathrm{SDi}<\mathrm{X}<\mathrm{Mi}$ & Rendah \\
$-0,5 \mathrm{Sdi}$ & \\
\hline $\mathrm{X}<\mathrm{Mi}-1,5 \mathrm{Sdi}$ & Sangat Rendah \\
\hline
\end{tabular}

Tabel 03. Kategori Penskoran Purposive Sampling

\begin{tabular}{|c|c|}
\hline $\begin{array}{c}\text { Kategori } \\
\text { Penskoran }\end{array}$ & Kategori \\
\hline $160.5-200$ & Sangat Tinggi \\
\hline $133.5-159.5$ & Tinggi \\
\hline $106.5-132.5$ & Cukup \\
\hline $79.5-105.5$ & Rendah \\
\hline $40-78.5$ & Sangat Rendah \\
\hline
\end{tabular}


Pada penelitian ini sample yang akan di gunakan adalah sample yang memiliki perilaku pergaulan bebas yang berada pada kategori sangat tinggi (160,5-200) dan kategori tinggi (133.5-159.5).

\section{Rancangan Penelitian}

Penelitian ini merupakan quasi experimental (eksperimen semu), dengan menggunakan rancangan Non Equivalent Pretest-Posttest Control Group Design. Rancangan control group design dipilih dengan pertimbangan bahwa dalam eksperimen semu, tidak memungkinkan untuk merandom subjek dalam kelompok populasi secara utuh. Selanjutnya pretest dan posttest berarti memberikan tes kepada subjek sebelum dan setelah perlakuan diberikan pada masing-masing kelompok. Rancangan ini dipilih karena penelitian ini merupakan penelitian terapeutik untuk mengetahui efektivitas atau pengaruh perlakuan terhadap variabel terikat. Artinya rancangan pretest dan posttest digunakan untuk mengetahui efektivitas Konseling Rational Emotive Behavior Therapy (REBT) untuk meminimalisir tingkat pergaulan bebas pada siswa kelas XI SMK 17 Agustus 1945 Muncar.

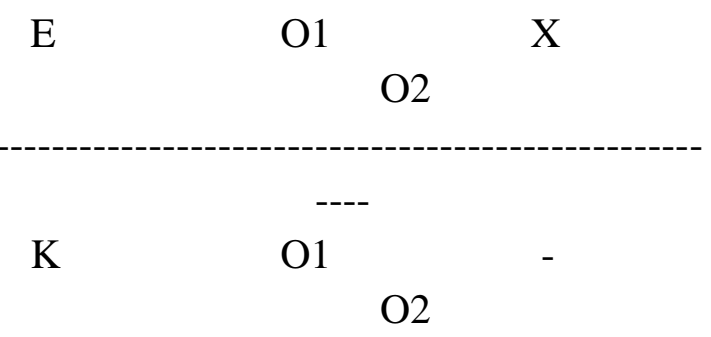

(Sumber: Dantes, 2012:97)

\section{Gambar 04. Desain Non}

Equivalent Pretest-Posttest Control

Group

\section{Keterangan :}

E : Kelompok Eksperimen

$\mathrm{K}$ : Kelompok Kontrol

$\mathrm{X}$ : konseling kelompok Pendekatan

REBT

- $\quad$ : konseling kelompok tanpa teknik

khusus

O1 : pengamatan awal, berupa pre-test sebelum diberikan perlakuan.

O2 : pengamatan akhir, yaitu pemberian post-test setelah diberikan perlakuan.

\section{Variabel Penelitian dan Definisi} Variabel

a. Identifikasi Variabel

Penelitian ini memiliki dua variabel utama yaitu variabel terikat dan variabel bebas. Variabel terikat adalah faktor yang diobservasi dan diukur untuk menentukan pengaruh variabel bebas. Sedangkan variabel bebas adalah faktor yang diukur, dimanipulasi atau dipilih oleh pelaksana eksperimen untuk menentukan hubungannya ke fenomena yang diobservasi.

Variabel yang dilibatkan dalam penelitian ini adalah:

Variabel bebas (X): Konseling REBT

Variabel terikat (Y): Pergaulan Bebas

b. Definisi Variabel

1) Definisi Konsep

a) Konseling REBT (Rational Emotif Behavior Therapy) ialah suatu pendekatan konseling yang mampu merubah pikiran dan tingkah laku individu yang bersifat irasional menjadi rasional. 
b) Pergaulan bebas adalah bentuk perilaku menyimpang yang melanggar aturan norma-norma atau aturanaturan agama ataupun normal sosial.

2) Definisi Operasional

a) Konseling REBT mempunyai tahapan - tahapan sebagai berikut:

(1) Tahap pertama, konselor harus berhasil menunjukkan kliennya bahwa pikirannya tidak logis atau irasional.

(2) Tahap kedua, konselor meyakinkan kepada kliennya bahwa pola pikir dapat diubah, sehingga kliennya benar-benar bersiap diri untuk menerima pikiran-pikiran yang rasional

(3) Tahap ketiga, konselor harus membuat kliennya mendebat (disputing) gangguan yang tidak tepat sekaligus yang tidak rasional yang telah dipertahankan dengan cara reindoktrinasi yang rasional, termasuk bersikap dan bertindak rasionalis

Pergaulan bebas terdiri dari Merokok, Minum-minuman keras, obatobatan terlarang, seks bebas.

\section{Metode Pengumpulan Data dan Instrumentasi}

Dalam metode pengumpulan data ini terdapat dua jenis metode Pengumpulan data yaitu metode pengumpulan data utama dan metode pengumpulan data pelengkap. Data-data yang akan dikumpulkan dengan menggunakan instrumen dan teknik pengumpulan data yang digunakan pada penelitian ini, lebih lanjut dapat dilihat berdasarkan Tabel berikut.

Tabel 05. Metode Pengumpulan Data

\begin{tabular}{|c|c|c|c|}
\hline $\begin{array}{c}\text { Varia } \\
\text { ble }\end{array}$ & $\begin{array}{c}\text { Metode } \\
\text { Pengum } \\
\text { pulan } \\
\text { Data }\end{array}$ & $\begin{array}{c}\text { Teknik } \\
\text { Pengump } \\
\text { ulan Data }\end{array}$ & $\begin{array}{l}\text { Instrumen } \\
\text { Penelitian }\end{array}$ \\
\hline & Utama & Kuesioner & $\begin{array}{c}\text { Kuesioner } \\
\text { Pergaulan } \\
\text { Bebas }\end{array}$ \\
\hline $\begin{array}{l}\text { Perga } \\
\text { ulan } \\
\text { Bebas }\end{array}$ & $\begin{array}{c}\text { Pelengka } \\
\mathrm{p}\end{array}$ & $\begin{array}{l}\text { Observasi } \\
\text { Dan } \\
\text { Wawancar } \\
\text { a }\end{array}$ & $\begin{array}{l}\text { 1. Pedoman } \\
\text { Observasi } \\
\text { Pergaulan } \\
\text { Bebas } \\
\text { 2. Pedoman } \\
\text { Wawancara } \\
\text { Pergaulan } \\
\text { Bebas }\end{array}$ \\
\hline
\end{tabular}

Data yang akan dikumpulkan adalah pergaulan bebas siswa, yang diukur dengan menggunakan instrumen berupa kuesioner pergaulan bebas. Instrumen tersebut diberikan kepada siswa sebelum pemberian perlakuan (pre-test) dan setelah perlakuan (post-test).

\section{a. Metode Pengumpulan Data}

\section{1) Metode Observasi}

Menurut Sugiyono (2016:145) Observasi sebagai teknik pengumpulan data mempunyai ciri yang spesifik bila dibandingkan dengan teknik yang lain, yaitu wawancara dan kuesioner. Kalau wawancara dan kuesioner selalu berkomunikasi dengan orang, maka observasi tidak terbatas pada orang, tetatpi obyek-obyek alam yang lain.

\section{2) Metode Wawancara}

Menurut Sugiyono

(2016:137)

Wawancara digunakan sebagai teknik pengumpulan data apabila peneliti ingin melakukan studi pendahuluan untuk menemukan permasalahan yang harus diteliti, dan juga apabila peneliti 
ingin mengetahui hal-hal dari responden yang lebih mendalam dan jumlah respondennya sedikit/kecil.

\section{3) Metode Kusioner}

Pengertian Kusioner merupakan teknik pengumpulan data yang dilakukan dengan cara memberi seperangkat pertanyaan atau pernyataan tertulis kepada responden untuk dijawabnya Sugiyono (2016:142).

\section{b. Instrumentasi}

\section{1) Konsepsi}

Instrumen penelitian adalah alat yang digunakan untuk mengumpulkan data dilapangan sesuai dengan kebutuhan penelitian guna mencapai tujuan penelitian. Penelitian ini juga menggunakan instrument berbentuk kuesioner (angket). Adapun langkahlangkah yang ditempuh dalam penyusunan kedua instrumen tersebut adalah: (1) menyusun kisi-kisi teks kuesioner pergaulan bebas siswa yang disesuaikan dengan komponen-komponennya, (2) penulisan butir-butir pernyataan pergaulan bebas siswa, (3) uji reliabitas dan validitas dengan bantuan SPSS 16. Terhadap kuesioner pergaulan bebas siswa, (4) uji coba kuesioner pergaulan bebas siswa, (5) analisis hasil uji coba kuesioner pergaulan bebas siswa, (6) revisi butir-butir pernyataan kuesioner pergaulan bebas siswa, (7) finalisasi instrument.

\section{2) Kisi-kisi/Panduan Instrumen}

Instrumen capaian pergaulan bebas disusun dengan menggunakan kuesioner. Berdasarkan kuesioner yang tersusun, akan diperoleh gambaran mengenai tingkat pergaulan bebas dari siswa kelas XI Akutansi SMK 17 Agustus 1945 Muncar tahun pelajaran 2017/2018 yang menjadi populasi dalam penelitian ini. Instrumen yang digunakan adalah kuesioner pergaulan bebas yang disusun sesuai dengan aspek pergaulan bebas. Kuesioner pergaulan bebas yang digunakan pada penelitian ini terdiri dari 40 butir pernyataan, dengan menggunakan skala Likert yang atas lima alternatif jawaban sesuai dengan tingkat keyakinan siswa.

\section{3) Validitasi/Uji Coba Instrumen}

(1) Validasi isi

Validitas isi adalah validitas yang ditentukan oleh derajat reprentativitas butir-butir instrument yang disusun telah mewakili keseluruhan materi yang hendak diukur tersebut. Untuk mengetahui validitas isi kuesioner pergaulan bebas yang digunakan, maka perlu dilakukan penilaian ahli (expert judgement) oleh dua orang ahli. Validitas isi tersebut berkenaan dengan kesanggupan dari alat penilaian dalam mengukur isi suatu variabel yang hendak diukur.

Berdasarkan pertimbanganpertimbangan yang diberikan oleh kedua orang ahli tersebut, hasil validitas kemudian dianalisis dengan menggunakan teknik analisis seperti berikut.

Tabel 08. Expert Judges untuk Pergaulan Bebas

\begin{tabular}{|l|l|l|}
\hline $\begin{array}{c}\text { Pakar 1 } \\
\text { Pakar 2 }\end{array}$ & $\begin{array}{c}\text { Kurang } \\
\text { relevan }\end{array}$ & $\begin{array}{l}\text { Sangat } \\
\text { relevan }\end{array}$ \\
\hline $\begin{array}{l}\text { Kurang } \\
\text { relevan }\end{array}$ & $\mathrm{A}$ & $\mathrm{B}$ \\
\hline $\begin{array}{l}\text { Sangat } \\
\text { relevan }\end{array}$ & $\mathrm{C}$ & $\mathrm{D}$ \\
\hline
\end{tabular}

(Sumber: Candiasa,2011)

Keterangan : 
A : Sel yang menunjukkan ketidaksetujuan antara kedua pakar

$\mathrm{B}$ dan $\mathrm{C} \quad$ : Sel yang menunjukkan perbedaan pandangan antara kedua pakar D : Sel yang menunjukkan persetujuan yang valid antara kedua pakar Hasil dari proses klasifkasifikan berdasarkan formula diatas, selanjutnya dimasukkan kedalam rumus berikut:

$$
\mathrm{V}_{1}=\frac{D}{A+B+C+D}
$$

Keterangan:

(Sumber: Candisa,2011)

V : validitas konten
A : kedua judges tidak setuju
B : judges I setuju, judges II tidak setuju
$\mathrm{C}$ : judges I tidak setuju, judges II setuju
D : kedua judges tidak setuju

Selanjutnya, Koyan (2012:78) menjelaskan bahwa semakin besar validitas isi butir dan untuk test baku nilai validitas isi butir Dan untuk test baku nilai validitas isi harus $\geq 0,90$.

(2) Validitas butir

Setelah analisis validitas isi tersebut, dilanjutkan dengan melakukan uji validitas butir melalui analisis butir. Suatu angket (kuesioner) dikatakan valid jika pernyataan atau pernyataan pada suatu kuesioner mampu untuk mengungkapkan sesuatu yang akan diukur oleh kuesioner tersebut. (Nurkancana,1990:232)

Dalam penelitian ini nilai kevaliditasan suatu data atau butir pernyataan berdasarkan r Product Moment. Pengujian ini dilakukan dengan cara membandingkan skor $r_{\text {hitung }}$ dengan $r_{\text {tabel }}$ dengan taraf signifikan 5\%. Rumus yang digunakan 94nstrumen korelasi Product Moment.

$$
r=\frac{\mathrm{N} \Sigma \mathrm{XY}-(\Sigma \mathrm{X})(\Sigma \mathrm{Y})}{\sqrt{\left[\mathrm{N} \Sigma X^{2}-(\Sigma \mathrm{X})^{2}\right]-\left[\mathrm{N} \Sigma Y^{2}-(\Sigma \mathrm{Y})^{2}\right]}}
$$

(Sumber : Nurkancana, 1990:232)

Keterangan:

$$
\begin{array}{ll}
\mathrm{r} & : \text { Koefisien Korelasi } \\
& : \text { Skor butir } \\
\mathrm{Y} & : \text { Skor total } \\
\mathrm{N} & \text { : Jumlah Responden }
\end{array}
$$

(3) Realiabilitas Butir

Setelah validitas isi dan validitas butir dilakukan, maka selanjutnya dilakukan uji reliabilitas (keandalan). Suatu kuesioner dikatakan reliable "apabila tes tersebut menunjukkan hasilhasil yang mantap". (Nurkancana, 1993:144). Reliabilitas tes merujuk kepada konsistensi hasil pengukuran apabila instrument itu digunakan oleh orang atau kelompok orang yang sama dalam waktu berlainan atau apabila 94nstrument itu digunakan oleh orang atau kelompok orang yang berbeda dalam waktu yang sama atau dalam waktu yang berlainan (Suryabrata, 2005). Pengukuran yang konsisten akan memberikan hasil yang sama untuk subyek yang sama pada waktu yang berbeda. Koefisien reliabilitas tes dapat bernilai antara 0.00-1.00.

Bentuk instrument yang dibuat adalah menggunakan instrument monodikotomis, maka konsistensi internal tes (reliabilitas tes) dietimasi berdasarkan koefisien Alpha Cronbach. Koefisien Alpha Cronbach dapat dihitung dengan formula berikut.

$\alpha=\frac{n}{n-1}\left[1-\frac{\Sigma s^{1} i}{s^{2} x}\right]$

(Mehrens \& Lehmann, 1984) 
Keterangan:

$\mathrm{N}$ : jumlah butir tes

$\mathrm{S}^{2} \mathrm{i}$ : $\quad$ varian butir

$\mathrm{S}^{2} \mathrm{i}$ : $\quad$ varian total tes

Koefisien reliabilitas secara wajar bergerak pada interval 0.00-1.00. Adapun kriteria reliabilitas suatu tes tersebut: $0,00-0,20$ adalah sangat rendah, $0.20-0.40$ adalah rendah, 0.40-0.60 adalah sedang, 0.60-0.80 adalah tinggi, dan 0.80-1.00 adalah sangat tinggi. Karena keterbatasan kemampuan yang dimiliki, maka uji validitas dan uji reliabilitas dibantu dengan program SPSS.16.0 for Windows.

\section{Metode Analisis Data}

\section{a. Deskripsi Data}

\section{(1) Teknik Analisis Deskriptif}

Data instrumen pergaulan bebas dianalisis secara deskriptif dan dinyatakan dengan jenjang kualifikasi. Jenjang kualifikasi dikategorikan berdasarkan skor rata-rata $(\bar{x})$ mean ideal $(\mathrm{Mi})$, dan standar deviasi ideal $\left(\mathrm{SD}_{\mathrm{i}}\right)$. Rumus untuk Mi dan $\mathrm{SD}_{\mathrm{i}}$.

$\mathrm{Mi}=\frac{1}{2}$ (skor tertinggi ideal + skor terendah ideal)

$\mathrm{SDi}=\frac{1}{6}$ (skor tertinggi ideal - skor terendah ideal)

Rerata skor $(\bar{X})$ dihitung dengan rumus $\bar{X} \frac{\Sigma x}{N}$, dimana $\sum \mathrm{X}=$ jumlah skor seluruh siswa dan $\mathrm{N}=$ jumlah siswa total. Semua analisis data yang dilakukan secara deskriptif menggunakan bantuan program Microsoft Office Excel for Windows 2007 dan SPSS 16.0 for Windows. Adapun berdasarkan jenjang kualifikasi diatas diperoleh pedoman skor untuk pergaulan bebas.

(2) Uji Prasyarat Analisis

(a) Uji Normalitas

Uji normalitas sebaran data dilakukan untuk meyakinkan bahwa data dihasilkan dalam penelitian benar-benar berdistribusi normal, sehingga uji hipotesis dapat dilakukan. Uji normalitas sebaran data menggunakan statistik KolmogorovSmirnov Test dan Shapiro Wilk Test (Candiasa, 2004). Uji ini dapat dilakukan dengan memanfaatkan bantuan SPSS 16.0 for Windows. Kriteria pengujiannya adalah data memiliki sebaran distribusi normal jika angka signifikansi yang diperoleh lebih besar dari 0,05 dan dalam hal lain sebaran tidak berdistribusi normal.

(b) Uji Homogenitas

Uji homogenitas digunakan untuk mengetahui apakah kelompokkelompok sampel berasal dari populasi yang sama. Kesamaan asal sampel ini dibuktikan dengan adanya kesamaan varians kelompok-kelompok yang membentuk sampel tersebut. Jika tidak ada perbedaan varians anatara kelompokkelompok sampel ini berarti bahwa kelompok tersebut bersifat homogen, sehingga dapat disimpulkan bahwa kelompok sampel tersebut berasal dari populasi yang sama (Sugiyono, 2010). Uji homogenitas varians antar kelompok menggunakan Levene's Test of Equality of Error Variance (Candiasa, 2004). Uji ini dapat dilakukan dengan memanfaatkan bantuan SPSS 16.0 for Windows. Pedoman yang digunakan untuk menetapkan homogenitas, yaitu (1) menetapkan saraf signifikansi ( $\alpha=0.05)$, (2) jika signifikansi yang diperoleh $>\alpha$, maka varians setiap 
sampel sama (homogen), (3) jika signifikansi yang diperoleh $<\alpha$, maka varians setiap sampel tidak sama (tidak homogen).

$$
W=\frac{(n-k) \Sigma_{t=1}^{k} n_{i}\left(\bar{z}_{i}-\bar{z}_{. .}\right)^{2}}{(k-1) \Sigma_{t=n^{\prime}}^{k} \sum_{j=1}^{n i}\left(\bar{z}_{t j}-\bar{z}_{t,}\right)^{2}}
$$

(Sumber: Sugiyono, 2010)

(c) Uji Hipotesis

Sebagai langkah lebih lanjut dalam penelitian ini, dilakukan suatu prosedur analisis terhadap data-data yang diperoleh peneliti. Tujuan dari analisis data ini adalah mengungkapkan apa yang ingin diketahui dari penelitian ini.

Dalam menganalisis data yang diperoleh selama melakukan penelitian, penulis menggunakan dua analisis statistik, antara lain: (1) analisis statistik correlated data/paired sampel t-test dan (2) analisis statistik uncorrelated data/independent sampel t-test.

Dasar pengambilan keputusannya adalah :

(1) Jika t hitung $>\mathrm{t}$ tabel, maka $\mathrm{H}_{0}$ ditolak

(2) Jika t hitung $<\mathrm{t}$ tabel, maka $\mathrm{H}_{0}$ diterima

Berdasarkan nilai probabilitasnya:

(1) Jika probabilitas > 0,05 maka $\mathrm{H}_{0}$ diterima

(2) Jika probabilitas $<0,05$ maka $\mathrm{H}_{0}$ ditolak

Analisis statistik correlated data/paired sampel t-test dimaksudkan untuk mengatahui efektivitas atau pengaruh dari variabel bebas terhadap variabel terikat dilihat dari perbedaan pretest dengan posttest (Seniatai, Yulianto dan Setiadi, 2005:119).
Hipotesis I berbunyi :

$\mathrm{H}_{0}$ : konseling Rational Emotive Behavior Therapytidak efektif untuk meminimalisir tingkat pergaulan bebas pada siswa kelas XI Akutansi SMK 17 Agustus 1945.

$\mathrm{H}_{\mathrm{a}}$ : konseling Rational Emotive Behavior Therapy efektif untuk meminimalisir tingkat pergaulan bebas pada siswa kelas XI Akutansi SMK 17 Agustus 1945 Muncar.

Rumus Uji Hipotesis I :

$$
\mathrm{T}=\frac{\left(X_{1}-X_{2}\right)-0}{\mathrm{SD} / \sqrt{\mathrm{N}}}
$$

Keterangan :

$\begin{array}{ll}\mathrm{X} 1 & \text { : Pretest } \\ \mathrm{X} 2 & \text { : Posttest } \\ \mathrm{SD} & \text { : Standar Deviasi } \\ \mathrm{N} & \text { : Jumlah data }\end{array}$

Analisis statistik uncorrelated
data/ independent sampel t-test dimaksudkan untuk membandingkan rata-rata dari dua grup yang tidak berhubungan satu dengan yang lain, apakah kedua grup tersebut mempunyai rata-rata yang sama ataukah tidak secara signifikan (Santoso, 2000:94).

Hipotesis II berbunyi :

$\mathrm{H}_{0}$ : Tidak terdapat perbedaan penurunan tingkat pergaulan bebas antara kelompok eksperimen dan kelompok kontrol.

$\mathrm{H}_{\mathrm{a}}$ : Terdapat perbedaan penurunan tingkat pergaulan bebas antara kelompok eksperimen dan kelompok kontrol.

Rumus Uji Hipotesis II:

Keterangan :

$$
t=\frac{\bar{X}_{1}-\bar{X}_{2}}{\sqrt{\frac{s_{1}{ }^{2}}{n_{1}}+\frac{s_{2}}{n_{2}}-2 r\left(\frac{s_{1}}{\sqrt{n_{1}}}\right)\left(\frac{s_{2}}{\sqrt{n_{2}}}\right)}}
$$

$\mathrm{X} 1$ : rata-rata skor kelompok eksperimen 
$\mathrm{X} 2$ : rata-rata skor kelompok kontrrol

SS1 : sum of square kelompok eksperimen

SS2 : sum of square kelompok kontrol n1 : jumlah subjek kelompok eksperimen n2 : jumlah subjek kelompok kontrol

\section{DAFTAR PUSTAKA}

Aqib, Z. 2013. Konseling Kesehatan Mental. Bandung: CV Yrama Widya

Candiasa, I. M. 2011. Statistik Multivariant Disertai Aplikasi SPSS. Singaraja: Undiksha Press.

Chomaria, N. 2008. Pergaulan Bebas. Solo : Samudra.

Depdiknas. 2008. Kamus besar bahasa Indonesia. Jakarta : Depdiknas.

Ghufron, M, N. \& Risnawati, R. 2012. Teori-Teori Psikologi. Jogjakarta : AR-RUZ Media

Gunarsa, Y, S, D. \& Gunarsa, S, D. 2012. Psikologi untuk muda - mudi. Jakarta : BPK Gunung Mulia.

Hadi, S. 2002. Statistik Jilid 2. Yogyakarta: Andi Yogyakarta.

Hayat, A. 2010. Teori dan Teknik Pendekatan Konseling. Banjarmasin: Lating Media Aksara.

Koyan. I. W. 2012. Statistik Pendidikan (Teknik Analisis Data Kuantitatif). Singaraja: Undiksha Press.

Natawidjaya, R. 2009. Konseling Kelompok Konsep Dasar \& pendekatan. Bandung: Rizqi Press.

Narwoko, D. dkk. 2013. Sosiologi Teks Pengantar dan Terapan. Jakarta : Kencana

Nursalim, M. Siti, N. 2013. Penerapan Layanan Informasi Bimbingan Pribadi Untuk Meningkatkan Pemahaman Siswa Mengenai Dampak Perilaku Seks Bebas di SMAN 1 SUGIHWARAS BOJONEGORO. Jurnal BK
UNESA, Vol 04, No 01, Halaman 144-153

Prayitno. 2008. Layanan Bimbingan dan Konseling Kelompok. Jakarta: Ghalia Indonesia

Rahardjo, W. 2008. Perilaku Seks Pranikah pada Mahasiswa Pria: Kaitannya dengan sikap terhadap Tipe Cinta Eros dan Ludus, Fantasi Erotis. Indigenous, Jurnal Ilmiah Berkala Psikologi. Vol. No 1, Halaman 1-2

Rahman. 2009. Menjaga akidah dan Akhlak. Surakarta : PT Tiga Serangkai.

Riko. 2015. Penanggulangan Kenakalan Siswa. Laporan Hasil Penelitian IAIN kendari

Sarwono, S, W. 2012. Psikologi Remaja. Jakarta: PT Raja Grafindo Persada.

Sukardi, K, D. \& Kusmawati, N. 2008. Proses Bimbingan dan Konseling di Sekolah. Jakarta : PT. Rineka Cipta

Sugiyono. 2016. Metode Penelitian Kuantitatif, Kualitatif, dan $R \& D$. Bandung:AFABETA,cv.

Surya, M. 2003. Teori-teori Konseling. Bandung : PustakaBani Quraisy.

Syah, M. 2000. Psikologi Pendidikan dengan Pendekatan Baru 